\title{
Gossypol-induced modifications in the microenvironment of rat epididymal spermatozoa
}

\author{
J. C. Soufir, C. Radigue, M. C. Dantec, D. Garnier* and B. Jegou* \\ Laboratoire de Biologie Cellulaire, Faculté de Médecine de Paris-Sud, 62 rue Gabriel Péri, \\ 94275 Kremlin Bicêtre, France; and * Laboratoire de Biologie de la Reproduction, Université de \\ Rennes 1, Campus de Beaulieu, Avenue du Général Leclerc, 35042 Rennes Cedex, \\ France
}

\begin{abstract}
Summary. Gossypol acetic acid $(20,25$ or $30 \mathrm{mg} / \mathrm{kg} /$ day orally for 5 weeks) decreased epididymal weight in adult Sprague-Dawley rats but the epididymal concentrations of proteins, lactate dehydrogenase and acid phosphatase were unchanged. The concentrations of carnitine, inositol and potassium in epididymal fluid were decreased in a dose-related manner. These modifications were not due to disturbances of Leydig and Sertoli cell functions which were normal. We suggest that the reduction in epididymal secretion results from a decrease in the number of spermatozoa rather than from a direct action of gossypol on the epididymal epithelium.
\end{abstract}

Keywords: gossypol; rat; epididymis; carnitine; inositol

\section{Introduction}

In the rat, after treatment with gossypol for 5 weeks, there is a decrease in the number and motility of epididymal spermatozoa as well as major morphological disturbances (breakages of flagella, vacuolization of mitochondria) (Oko \& Hrudka, 1982; Hoffer, 1983; Chang \& Segal, 1985; Baccetti et al., 1986). However, the mechanisms by which these lesions occur are not clear. Some authors have suggested that gossypol does not affect the epididymis and propose that the anomalies of epididymal spermatozoa are the consequences of an effect at the testicular level during spermatogenesis (Hoffer, 1983), whereas others believe that gossypol has a direct action at the level of epididymis and that this can occur from the 5 th day of treatment (Wang et al., 1986; Baccetti et al., 1986).

Similarly, there is no agreement about the effects of gossypol on the epididymal epithelium; Hoffer $(1983,1985)$ found no effect but others report major lesions of the epithelium in the corpus and cauda epididymidis. These include narrowing of the walls of the tubules, thickening of the epithelium, increase in the intensity of staining for acid phosphatase and dissociation of the basal membrane of the smooth muscle layer (Zhou et al., 1985a, b), focal loss of cilia and cytoplasmic vacuolization (Kaur et al., 1988). There have been few studies on the modifications induced by gossypol in the biochemical composition of the epididymis. Wong et al. (1983) reported an increase in sodium in the epididymal fluid but explained this by an effect on the Sertoli cell. In a preliminary study, we demonstrated a large fall in epididymal carnitine, the concentration of which is closely correlated with the metabolic maturation and the motility of epididymal spermatozoa (Soufir et al., 1984). These results have since been confirmed by Giridharan $e t$ al. (1987).

The aim of this study was to clarify the nature, the degree and the regional distribution of the biochemical modifications in the epididymis induced by gossypol and to study the role of Leydig and Sertoli cell functions in these changes. 


\section{Materials and Methods}

\section{Animals and treatment}

Adult Sprague-Dawley rats (320-380 g body weight: Iffa Credo, l'Arbresle, France) were allowed free access to food and water and given gossypol tetra-acetic acid freshly suspended in sesame oil by gavage 6 days a week for 5 weeks. The gossypol tetra-acetic acid was kindly provided by Dr J. Posti (Leiras Pharmaceutical, Turku, Finland). The controls received an equal volume of diluent.

In Exp. I, 2 batches of 25 rats received 20 or $30 \mathrm{mg}$ gossypol tetra-acetic acid $/ \mathrm{kg} /$ day and 1 batch of 15 rats was used as controls. In Exp. 2, 5 received $25 \mathrm{mg} / \mathrm{kg} /$ day and 5 acted as controls.

After the treatment period the animals were decapitated and blood was recovered and coagulated. The serum was preserved at $-20^{\circ} \mathrm{C}$. The testes and epididymides were dissected and weighed.

\section{Epididymal measures}

Measurement of sperm motility. A drop of fluid from the cauda epididymidis was placed in the well of a cavity slide containing $0.2 \mathrm{ml}$ modified B2 medium (Menezo, 1976) at $37^{\circ} \mathrm{C}$. The composition of the medium $(\mathrm{mmol} / \mathrm{l}$ ) was $\mathrm{NaCl}$, $89 ; \mathrm{NaHCO}_{3}, 29 ; \mathrm{KCl}, 10 ; \mathrm{MgSO}_{4} \cdot 2\left(\mathrm{H}_{2} \mathrm{O}\right), 1.66 ; \mathrm{KH}_{2} \mathrm{PO}_{4}, 0.44$; sodium acetate, 0.6 ; calcium lactate, $1.68 ;$ sodium pyruvate, $2 \cdot 27$; bovine serum albumin, $0 \cdot 117$; glucose, $6 \cdot 66$. The percentage of motile spermatozoa was estimated immediately by light microscopy (Nachet 200$)$ at low magnification $(\times 100)$.

Morphological study of spermatozoa. A drop of epididymal fluid was diluted in $0.5 \mathrm{ml}$ Tyrode's solution then spread out on a slide by tipping. After fixation in ethyl alcohol (v/v) for $1 \mathrm{~h}$, the preparation was stained using Shorr's haematoxylin technique. It was observed under a Univar microscope at magnifications of $\times 400$ and $\times 1000$.

Preparation of epididymal supernatants. At autopsy, epididymides were immediately frozen and stored in liquid nitrogen. Frozen epididymides were ground in a porcelain mortar under liquid nitrogen and the powder was then homogenized in a Teflon glass homogenizer in Tris buffer $(10 \mathrm{mmol} / \mathrm{l}) \mathrm{pH} 7.4$ and EDTA $(1.5 \mathrm{mmol} / 1)(200 \mathrm{mg}$ powder $/ \mathrm{ml}$ ) in the presence of phenylmethylsulphonyl fluoride (PMSF: $200 \mathrm{mmol} / \mathrm{l}, 25 \mu \mathrm{l} / 10 \mathrm{ml}$ suspension). The homogenates were then centrifuged at $14000 \mathrm{~g}$ for $20 \mathrm{~min}$. The supernatants were divided into 2 halves; the first was used for the enzyme and protein assays and the second deproteinized by centrifugation at $1000 \mathrm{~g}$ at $4^{\circ} \mathrm{C}$ using an Amicon CF 50 A filter.

Epididymal sperm reserves. After thawing, the epididymides were divided into 2 regions (caput and corpus-cauda) by cutting at the narrow corpus region. Each portion was minced and homogenized in 25 ml saline-Triton solution (150 mmol NaCl/l; 0.05\% (v/v) Triton X-100). Sperm reserves were then counted as described by Robb et al. (1978).

Spermatocrit. Fluids from the caput and cauda epididymidis were obtained by micropuncture using a heparinized capillary tube (Propper, Long Island, NY, USA) then centrifuged at $15000 \mathrm{~g}$ at room temperature for $25 \mathrm{~min}$ (Bioblock Scientific TH-12 centrifuge). The spermatocrit was calculated by dividing the height of the pellet by the height of the total contents and expressed as a percentage.

The epididymal plasma (supernatant) was then recovered, diluted to $1 / 30$ in distilled water and stored at $-30^{\circ} \mathrm{C}$

Biochemical determinations. All compounds were assayed in duplicate and blanks were run concurrently.

The activities of lactate dehydrogenase (EC 1.1.2.3) (LDH), an enzyme associated with glycolysis, and acid phosphatase (EC 3.1.3.2), a marker of lysosomes, were determined in supernatants of $14000 \mathrm{~g}$ homogenates. These enzymes were chosen because gossypol is known to inhibit dehydrogenases (Lee et al., 1985) and to increase acid phosphatase staining in the epididymal epithelium (Zhou et al., 1985b). The procedures of determination were based on an ultraviolet method for LDH (Bergmeyer \& Bernt, 1974) and a colorimetric method for acid phosphatase (Sigma Technique No. 104). The final concentrations of the components of the reaction media were sodium phosphate buffer, $50 \mathrm{mmol} / 1, \mathrm{pH} 7.5$; pyruvate $0.6 \mathrm{mmol} / \mathrm{l}$; NADH, $0.18 \mathrm{mmol} / \mathrm{l}$ with $0.010 \mathrm{ml}$ epididymal supernatant for LDH and sodium citrate buffer $(36 \mathrm{mmol} / \mathrm{l}, \mathrm{pH} \mathrm{5.5})$, paranitrophenylphosphate $(0.250 \mathrm{ml}$ of a $4 \mathrm{mg} / \mathrm{ml}$ solution) with $0 \cdot 1 \mathrm{ml}$ epididymal supernatant for acid phosphatase. The final assay volume was $0.620 \mathrm{ml}$ for $\mathrm{LDH}$ and $0.600 \mathrm{ml}$ for acid phosphatase and the measurements were read at $334 \mathrm{~nm}$ for LDH and $405 \mathrm{~nm}$ for acid phosphatase.

Protein concentrations were determined according to the method of Lowry et al. (1951).

Inositol was measured using the technique of Weissbach (1974). Briefly, assay tubes contained 156 mmol sodium carbonate buffer/l (pH 9.5), 3.125 mmol NAD/1 and $0.02 \mathrm{ml}$ of a suspension of inositol dehydrogenase (EC 1.1.1.8) at $4 \times 10^{3} \mathrm{U} / 1$. The volume of the sample was $0.050 \mathrm{ml}$ for a total volume in the cuvette of $0.675 \mathrm{ml}$ for the supernatants and $0.320 \mathrm{ml}$ for diluted epididymal plasmas.

Free L-carnitine determinations were made by the spectrophotometric method of Marquis \& Fritz (1964) as modified by Soufir et al. (1981). Assay tubes contained $125 \mathrm{mmol}$ Hepes buffer/l (pH 7.8), 0.25 mmol DTNB (5,5'dithiobis 2 -nitrobenzoic acid)/ml, $0.19 \mathrm{mmol}$ acetylcoA/l and $0.02 \mathrm{ml}$ of a suspension of $400 \times 10^{3} \mathrm{U}$ carnitine acetyltransferase (CAT; EC 2.3.1.7). The volume of the sample was $0.010 \mathrm{ml}$ for the supernatant of the homogenate, $0.20 \mathrm{ml}$ for diluted caput epididymal plasma and $0.02 \mathrm{ml}$ for diluted cauda epididymal plasma, all in a total volume in the cuvette of $0.6 \mathrm{ml}$. 
Acetylcarnitine was determined using the method of Marquis \& Fritz (1965) and Pearson et al. (1974). Assay tubes contained $125 \mathrm{mmol}$ Hepes buffer $/ \mathrm{ml}(\mathrm{pH} 7.8), 3 \mathrm{mmol} \mathrm{NAD} / 1,0.13 \mathrm{mmol}$ coenzyme A/ml, $1.6 \mathrm{mmol}$ EDTA/l, $13 \mathrm{mmol}$ potassium malate $/ 1,0.010 \mathrm{ml}$ of a suspension of malate dehydrogenase $(\mathrm{EC} 1.1 .1 .37)$ at $6 \times 10^{6} \mathrm{U} / 1,0.010 \mathrm{ml}$ of a suspension of citrate synthase (EC 4.1.3.7) at $1 \cdot 1 \times 10^{6} \mathrm{U} / 1$ and $0.010 \mathrm{ml}$ of a suspension of CAT (EC 2.3.1.7) at $400 \times 10^{3} \mathrm{U} / 1$.

Determinations of inositol and acetylcarnitine were read at $334 \mathrm{~nm}$ and those of carnitine at $405 \mathrm{~nm}$.

Enzyme specific activity was calculated as mmol substrate utilized per minute per milligram (mg) protein.

\section{Potassium}

Potassium was measured by the potentiometric technique using a Beckman selective electrode. The apparatus was calibrated to measure a range of concentrations between 1 and $10 \mathrm{mmol} / \mathrm{l}$.

\section{Testicular measures}

Testicular fluid production was measured by unilateral efferent duct ligature (EDL) for $16 \mathrm{~h}$ as previously described (Jegou et al., 1983).

Androgen-binding protein ( $A B P$ ). The technique used was that of Hagenäs \& Ritzen (1976) as modified by Jegou et al. (1983). Homogenates (see preparation of epididymal supernatants) of the caput epididymidis were centrifuged in a Beckman ultracentrifuge $(\mathrm{L} 855 \mathrm{M})$ at $105000 \mathrm{~g}$ for $1 \mathrm{~h} \mathrm{at} 4^{\circ} \mathrm{C}$. The supernatants were obtained and frozen at $-20^{\circ} \mathrm{C}$. For the assay one sample $(150 \mu \mathrm{l})$ of each supernatant was incubated for $2 \mathrm{~h}$ with $2 \mathrm{nmol}\left[{ }^{3} \mathrm{H}\right] 5 \alpha$-dihydrotestosterone (DHT). A $50-\mu \mathrm{l}$ sample was then deposited on a polyacrylamide gel $(6.5 \%$ acrylamide, $0 \cdot 15 \%$ bisacrylamide containing $2 \mathrm{nmol}\left[{ }^{3} \mathrm{H}\right] 5 \alpha$-DHT. ABP, like other proteins, migrates in the electric field in relation to its charge and its molecular weight. The electrophoresis lasted $3 \mathrm{~h}(1.5 \mathrm{~mA} /$ electrophoresis tube). The gels were then removed from the moulds, cut into $2 \mathrm{~mm}$ slices and immersed in $3 \mathrm{ml}$ Picofluor. The radioactivity was then measured with a Packard Tri-carb $460 \mathrm{C}$ counter. The sites of migration of ABP and albumin were noted by the radioactive peaks as these 2 proteins bound to the $5 \alpha-$ DHT.

In-vitro production of testosterone. After decapsulation, hemi-testes from the experimental animals (5 per group) were incubated for $4 \mathrm{~h}$ at $34^{\circ} \mathrm{C}$ in a shaking water bath in $2 \mathrm{ml}$ phosphate-buffered saline solution (PBS, $\mathrm{pH} \mathrm{7.4)}$ with the addition of glucose $(1 \mathrm{mg} / \mathrm{ml})$, as previously described (de Kretser $e t$ al., 1979; Jégou et al., 1984); one-half of each testis was used to indicate basal production of testosterone and the other half was stimulated by including hCG ( 700 mi.u./ml; Pregnyl: Organon; Eragny sur Epte, France) in the PBS. At the end of the incubation period the media were centrifuged at $2000 \mathrm{~g}$ for $15 \mathrm{~min}$ and the supernatants stored at $-20^{\circ} \mathrm{C}$ until assayed for testosterone.

Hormonal measurements. Concentrations of testosterone in serum were measured after extraction with a mixture of cyclohexane-ethyl acetate $(1: 1, \mathrm{v} / \mathrm{v})$ using a radioimmunoassay previously described by Garnier et al. (1978). The antiserum was raised in a rabbit against testosterone 3-O-carboxymethyloxime-bovine serum albumin (final dilution 1/15000) prepared by Dr M. Terqui and Dr D. H. Garnier at CRVZ.INRA (Nouzilly). This antiserum cross-reacts with dihydrotestosterone ( $60 \%$ with $5 \alpha$-DHT and $20 \%$ with $5 \beta$-DHT) and $5 \alpha$-androstanediol $(36 \%$ with $3 \alpha, 17 \beta$ - and $25 \%$ with $3 \beta, 17 \beta$-androstanediol). The intra-assay coefficient of variation ranged from 7.5 to $9.5 \%$ according to the levels assayed. All samples were measured in one assay.

Concentrations in the incubation media were assayed without extraction as described by Garnier et al. (1978). This had no effect on the results (data not shown). The intra-assay coefficient of variation was $7 \%$ and all samples were measured in one assay. The minimum detectable testosterone concentrations were $50-100 \mathrm{pg} / \mathrm{ml}$.

\section{Statistical analyses}

Data were analysed by conventional statistical tests such as analysis of variance and $t$ tests.

\section{Results}

\section{Weight of testes and epididymides (Table 1)}

There was no significant variation in the weight of the testes. However, there was a significant decrease in the weight of the epididymis by about $10 \%$ in both studies. 
Table 1. Effects of gossypol on the weight (g) of testes and epididymides in rats

\begin{tabular}{|c|c|c|c|c|c|}
\hline & \multicolumn{3}{|c|}{ Experiment 1} & \multicolumn{2}{|c|}{ Experiment 2} \\
\hline & \multirow[b]{2}{*}{ Controls } & \multicolumn{2}{|c|}{ Gossypol } & \multirow[b]{2}{*}{ Controls } & \multirow{2}{*}{$\begin{array}{c}\text { Gossypol } \\
25 \mathrm{mg} / \mathrm{kg} / \mathrm{day}\end{array}$} \\
\hline & & $20 \mathrm{mg} / \mathrm{kg} / \mathrm{day}$ & $30 \mathrm{mg} / \mathrm{kg} /$ day & & \\
\hline No. of rats & 15 & 25 & 22 & 5 & 5 \\
\hline Testes & $1.88 \pm 0.04$ & $1.92 \pm 0.03$ & $1.85 \pm 0.03$ & $2.01 \pm 0.05$ & $2 \cdot 16 \pm 0 \cdot 1$ \\
\hline Epididymides & $0.65 \pm 0.01$ & $0.59 \pm 0.01^{* *}$ & $0.57 \pm 0.01^{* *}$ & $0.63 \pm 0.02$ & $0.56 \pm 0.03^{*}$ \\
\hline
\end{tabular}

Values are mean \pm s.e.m.

${ }^{*} P<0.01 ;{ }^{* *} P<0.001$ compared with controls $(t$ test $)$.

\section{Epididymides}

Motility, number and morphology of epididymal spermatozoa (Table 2)

At a dose of $20 \mathrm{mg} / \mathrm{kg} / \mathrm{day}$, almost all of the spermatozoa were immotile in 3 of the 5 rats and in the other 2 the motility was between 35 and $40 \%$. In the rats treated with 30 or $25 \mathrm{mg} / \mathrm{kg} / \mathrm{day}$ all the spermatozoa from the cauda epididymidis were immotile.

Gossypol at $20 \mathrm{mg} / \mathrm{kg} /$ day did not result in a significant change in the number of spermatozoa in the caput epididymis although a drop of $50 \%$ was observed in the cauda epididymidis. Treatment with $30 \mathrm{mg}$ gossypol $/ \mathrm{kg} /$ day caused a decrease in the sperm reserves in the caput and an even greater reduction in the cauda epididymidis (a drop of $65 \%$ ). At a dose of $25 \mathrm{mg} / \mathrm{kg} / \mathrm{day}$ a reduction in the spermatocrit of $42 \%$ was observed.

Table 2. Effects of gossypol on the motility and the number of epididymal spermatozoa in rats

\begin{tabular}{|c|c|c|c|c|c|}
\hline & \multicolumn{3}{|c|}{ Experiment 1} & \multicolumn{2}{|c|}{ Experiment 2} \\
\hline & \multirow[b]{2}{*}{ Controls } & \multicolumn{2}{|c|}{ Gossypol } & \multirow[b]{2}{*}{ Controls } & \multirow{2}{*}{$\begin{array}{c}\text { Gossypol } \\
25 \mathrm{mg} / \mathrm{kg} / \text { day }\end{array}$} \\
\hline & & $20 \mathrm{mg} / \mathrm{kg} /$ day & $30 \mathrm{mg} / \mathrm{kg} /$ day & & \\
\hline No. of rats & 5 & 5 & 5 & 5 & 5 \\
\hline $\begin{array}{l}\% \text { Motile spermatozoa } \\
\text { Sperm reserves } \\
\text { ( } \times 10^{-6} / \text { organ) }\end{array}$ & $61 \pm 8$ & $15 \pm 4$ & 0 & $90 \pm 3$ & 0 \\
\hline Caput & $66 \pm 9$ & $62 \pm 4$ & $45 \pm 4^{*}$ & - & - \\
\hline Cauda & $105 \pm 5$ & $54 \pm 16^{*}$ & $38 \pm 14^{*}$ & - & - \\
\hline Spermatocrit (\%) & & & & & \\
\hline Caput & - & - & - & $26 \pm 0 \cdot 4$ & $29 \pm 1$ \\
\hline Cauda & - & - & - & $53 \pm 4$ & $31 \pm 5^{* *}$ \\
\hline
\end{tabular}

Values are mean \pm s.e.m.

${ }^{*} P<0.05 ;{ }^{* *} P<0.001$ compared with controls $(t$ test $)$.

About $85 \%$ of the spermatozoa from the rats given $25 \mathrm{mg}$ gossypol $/ \mathrm{kg} /$ day were broken at the junction of the tail and the mid-piece. Only $6 \%$ of the remaining spermatozoa had a normal appearance, the other $7 \%$ demonstrating dislocations of the dense fibres or cytoplasmic droplets. Both of these anomalies were sometimes associated.

Biochemical composition of supernatants of whole epididymides (Table 3)

Epididymal protein concentration and enzyme activities. Treatment with gossypol did not change the concentration of proteins or the specific activities of LDH and acid phosphatase. 
Table 3. Effects of gossypol on the biochemical composition of the epididymis in rats

\begin{tabular}{|c|c|c|c|}
\hline & \multirow[b]{2}{*}{ Controls } & \multicolumn{2}{|c|}{ Gossypol } \\
\hline & & $20 \mathrm{mg} / \mathrm{kg} /$ day & $30 \mathrm{mg} / \mathrm{kg} /$ day \\
\hline $\begin{array}{l}\text { Proteins } \\
\quad(\mathrm{mg} / \mathrm{ml})\end{array}$ & $6 \cdot 3 \pm 0 \cdot 3$ & $6.3 \pm 0.3$ & $6 \cdot 3 \pm 0 \cdot 4 \quad(10)$ \\
\hline $\begin{array}{l}\text { Lactate dehydrogenase } \\
\text { (IU/mg protein) }\end{array}$ & $1 \cdot 6 \pm 0.1$ & $1.6 \pm 0.1$ & $1 \cdot 4 \pm 0 \cdot 1$ \\
\hline $\begin{array}{l}\text { Acid phosphatase } \\
\text { (U/mg protein) } \\
\text { Inositol }\end{array}$ & $3 \cdot 4 \pm 0 \cdot 1 \quad(6)$ & $3 \cdot 6 \pm 0 \cdot 1$ & $3 \cdot 4 \pm 0 \cdot 2$ \\
\hline $\begin{array}{l}\text { (nmol/mg protein) } \\
\text { Carnitine }\end{array}$ & $157 \pm 8$ & $132 \pm 9^{*}$ & $117 \pm 7^{*}$ \\
\hline $\begin{array}{l}\text { (nmol/mg protein) } \\
\text { Acetylcarnitine }\end{array}$ & $260 \pm 23$ & $125 \pm 22^{*}(8)$ & $80.5 \pm 9^{*}$ \\
\hline $\begin{array}{c}(\mathrm{nmol} / \mathrm{mg} \text { protein }) \\
\mathrm{K}(\mu \mathrm{mol} / \mathrm{ml} \text { supernatant })\end{array}$ & $29.4 \pm 4.6$ & $39 \cdot 4 \pm 5 \cdot 6$ & $31.4 \pm 8.8$ \\
\hline $\begin{array}{l}\text { Caput } \\
\text { Cauda }\end{array}$ & $\begin{array}{l}5.81 \pm 0.23(3) \\
6.14 \pm 0.04(3)\end{array}$ & $\begin{array}{l}5.65 \pm 0.06(3) \\
6.50 \pm 0.05(3)\end{array}$ & $\begin{array}{l}6.32 \pm 0.17 \\
6.18 \pm 0.53\end{array}$ \\
\hline
\end{tabular}

Values are mean \pm s.e.m. for the no. of animals in parentheses.

${ }^{*} P<0.01$ compared with controls ( $t$ test).

Table 4. Effects of gossypol $(25 \mathrm{mg} / \mathrm{kg} /$ day $)$ on the composition of epididymal fluid in rats

\begin{tabular}{lcc}
\hline & $\begin{array}{c}\text { Controls } \\
(\mathrm{N}=5)\end{array}$ & $\begin{array}{c}\text { Treated } \\
(\mathrm{N}=5)\end{array}$ \\
\hline $\begin{array}{l}\text { Inositol }(\mu \mathrm{mol} / \mathrm{ml}) \\
\text { Cauda }\end{array}$ & $32 \pm 2 \cdot 7$ & $13.8 \pm 3^{*}$ \\
Carnitine $(\mu \mathrm{mol} / \mathrm{ml})$ & $1.63 \pm 0.6$ & $2 \cdot 13 \pm 0.3$ \\
$\quad$ Caput & $25 \pm 4$ & $13 \pm 5^{*}$ \\
$\quad$ Cauda & & \\
Potassium $(\mu \mathrm{mol} / \mathrm{ml})$ & $16.5 \pm 0.75$ & $18.1 \pm 0.75$ \\
$\quad$ Caput & $26 \pm 3.4$ & $16.25 \pm 3^{*}$ \\
$\quad$ Cauda & & \\
\hline
\end{tabular}

Values are mean \pm s.e.m.

$* P<0.05$ compared with controls $(t$ test $)$.

Inositol, carnitine, acetylcarnitine and potassium. The levels of inositol and carnitine were reduced by treatment with gossypol and the decrease was dose-related. The reduction in inositol was less marked than that of carnitine: inositol fell by $16 \%$ at a dose of $20 \mathrm{mg} / \mathrm{kg} /$ day and $26 \%$ at $30 \mathrm{mg} / \mathrm{kg} /$ day whereas the respective figures for carnitine were $52 \%$ and $69 \%$. The concentrations of acetylcarnitine were not reduced and amounts of potassium were not modified in the caput or cauda epididymidis.

\section{Biochemical composition of epididymal fluid (Table 4)}

In control rats, the concentration of carnitine was 15 times greater in the cauda than in the caput. In the animals treated with $25 \mathrm{mg}$ gossypol $/ \mathrm{kg} /$ day the concentration of carnitine was unchanged in fluid from the caput but there was a reduction of $48 \%$ in fluid from the cauda. The decrease in inositol in fluid from the cauda was of a magnitude similar to that found with carnitine $(-43 \%)$, in contrast to the smaller change found in epididymal supernatants. In the control rats, potassium was 1.6 times greater in the cauda than in the caput with a difference of $10 \mu \mathrm{mol} / \mathrm{ml}$ 
Table 5. Effects of gossypol on Leydig and Sertoli cell characteristics

\begin{tabular}{|c|c|c|c|}
\hline & \multirow[b]{2}{*}{ Controls } & \multicolumn{2}{|c|}{ Gossypol } \\
\hline & & $20 \mathrm{mg} / \mathrm{kg} /$ day & $30 \mathrm{mg} / \mathrm{kg} /$ day \\
\hline $\begin{array}{l}\text { Serum testosterone } \\
\quad(\mathrm{ng} / \mathrm{ml})\end{array}$ & $1.47 \pm 0.21$ & $\begin{array}{c}2.55 \pm 0.63 \\
(20)\end{array}$ & $\begin{array}{c}2 \cdot 05 \pm 0.47 \\
(17)\end{array}$ \\
\hline $\begin{array}{l}\text { In-vitro testosterone basal } \\
\text { production (ng/testis } / 4 \mathrm{~h} \text { ) }\end{array}$ & $73 \cdot 6 \pm 9.6$ & $68 \pm \frac{ \pm}{(5)} 10 \cdot 4$ & $87 \cdot 2 \pm 30 \cdot 4$ \\
\hline $\begin{array}{l}\text { hCG stimulated production } \\
\text { (ng/testis } / 4 \mathrm{~h})\end{array}$ & $144 \cdot 8 \pm 48$ & $139 \cdot 2 \pm \frac{ \pm}{(5)} 43 \cdot 6$ & $219 \cdot 2 \pm 66 \cdot 0$ \\
\hline $\begin{array}{l}\text { Testicular fluid production } \\
(\mathrm{g} / 16 \mathrm{~h})\end{array}$ & $0.51 \pm 0.04$ & $0.47 \underset{(6)}{ \pm} 0.05$ & $0.49 \pm \frac{ \pm}{(6)} 0.05$ \\
\hline $\begin{array}{l}\text { ABP } \\
\text { (pmol/caput epididymidis) }\end{array}$ & $16 \cdot 13 \pm 1.88$ & $19.88 \underset{(5)}{ \pm} 1.88$ & $26 \cdot 25 \pm 3 \cdot 75$ \\
\hline
\end{tabular}

Values are mean \pm s.e.m. for the no. of rats in parentheses.

between these 2 regions. Gossypol at $25 \mathrm{mg} / \mathrm{kg} /$ day did not modify the concentration of potassium in fluid from the caput but caused a decrease of $40 \%$ in the cauda. This decrease is of the same magnitude as those of inositol and carnitine and was sufficient to equalize the potassium concentrations in the two regions.

\section{Testicular measures}

Gossypol at $20-30 \mathrm{mg} / \mathrm{kg} /$ day led to no significant change in serum testosterone (Table 5). Nor was the basal or hCG-stimulated production of testosterone in vitro affected.

There were no modifications in the amount of ABP in the caput epididymidis or in the production of testicular fluid by gossypol treatment.

\section{Discussion}

Administration of gossypol to rats for 34 days provoked disturbances in the biochemical composition of the epididymis. The epithelium did not appear to be damaged: the concentration of protein was not reduced and $\mathrm{LDH}$, a marker of the cytoplasmic compartment and acid phosphatase, a marker of the lysosomic compartment were both unchanged. Only the elements secreted into the epididymal fluid were decreased. This was the case regardless of whether the mechanism of secretion was by a process of uptake and concentration as for carnitine (Brooks, 1980), of synthesis from glucose as for inositol (Beyler \& Zaneveld, 1982), or ionic movements as for potassium (Mann, 1975). This reduction affected each of these elements to the same degree which suggests that the entire epididymal secretory process is affected. This might possibly explain the reduction in weight of the epididymides (see Table 1).

The reduction in epididymal secretion poses two questions: (1) could it be responsible for the reduction in the quality of epididymal spermatozoa which had been noted (breakage, immobilization) and (2) what is the mechanism which produces this fall in secretion? Epididymal fluid has a determinant role in the maturation of spermatozoa. The effect of each of the secreted elements on the spermatozoa is not clear. Nothing is known concerning the role of inositol and potassium whereas more information is available on carnitine which is concentrated in the fluid and penetrates the spermatozoa where it is transformed into acetylcarnitine. This transformation is correlated with the acquisition of motility by the spermatozoa (Jeulin et al., 1987). It has been demonstrated that, even though the epithelial cells capture and concentrate carnitine, the passage of carnitine into the spermatozoa appears to occur by passive diffusion (Jeulin et al., 1987). A deficiency of carnitine in the fluid could therefore be responsible for a deficit of carnitine and 
acetylcarnitine in the spermatozoa and this could lead to major metabolic disturbances and deterioration of the cells. However, even if this process does exist, it could only be a minor cause or simply aggravate the anomalies present in epididymal spermatozoa. There is agreement in several publications that the lesions of epididymal spermatozoa have previously been acquired in the testis at the stage of the late spermatids. The mitochondria are affected and these vacuolize then lyse (Hoffer, 1983; Radigue et al., 1988). Furthermore, it is probable that this mitochondrial lesion makes the spermatozoa incapable of creating the acetyl radicals necessary for the synthesis of acetylcarnitine.

Why should the epididymal secretion be reduced? It is not possible to exclude completely a direct action of gossypol on the epididymis. However, there are several reasons to evoke the hypothesis that the Leydig and Sertoli control mechanisms might be disturbed. It is known that, in vitro, gossypol induces a decrease in Leydig (Lin et al., 1981) and Sertoli (Oko \& Hrudka, 1984) functions. In fact our results prove that, in vivo, after 34 days of treatment there is no Sertoli deficiency: the level of ABP, which assures the transport of androgens in the epididymal lumen, is not modified and the production of testicular fluid, which is a further index of Sertoli function (Hagenäs \& Ritzen, 1976; Jegou et al., 1983), is also normal as it has previously been reported (Wong et al., 1984). Furthermore, neither serum testosterone nor testosterone synthesis by the testis are decreased. It is therefore very unlikely that the reduction in epididymal secretion is a consequence of an involvement of Sertoli or Leydig functions.

The results of several authors indicate that, in animals and man, the reduction in the number of spermatozoa produced by the testis is accompanied by modifications of the biochemical composition of the fluid. In the corpus epididymidis of the bull the reduction in spermatogenesis is accompanied by a $50 \%$ diminution in proteins and a $75 \%$ reduction in glycerophosphocholine (Gustafsson, 1966). In man, inhibition of sperm production by a combination of medroxyprogesterone acetate + testosterone leads to oligozoospermia, then azoospermia with a concomitant reduction in seminal carnitine (Soufir et al., 1983). These results seem to indicate that the presence of spermatozoa in the epididymis stimulates the production of certain components in the fluid and that this is relative to the number of spermatozoa. In this study, the reduction in the secretion of constituents of the fluid was of the same magnitude as that of the number of spermatozoa in the cauda epididymidis.

It must be stressed that treatment with gossypol does not cause the same effects as treatments with steroids. In the latter there is reduction in sperm production whereas with gossypol the production of spermatozoa is quantitatively unchanged (using doses of 20 and $25 \mathrm{mg} / \mathrm{kg} /$ day). However, during the course of epididymal transit there is lysis of spermatozoa which leads to the reduction observed in the cauda epididymidis.

Conclusive interpretation of the results needs further work. Nevertheless, the available data suggest that the structural alterations of spermatids and spermatozoa induced by gossypol could be responsible for the decreased number and motility and the morphological alterations of epididymal spermatozoa inside the epididymal lumen. We suggest that the reduction in epididymal secretion results from the decreased number of spermatozoa rather than from a direct action of gossypol on epididymal epithelium.

\section{References}

Baccetti, B., Bigliardi, E., Burrini, A.G., Renieri, T. \& Selmi, G. (1986) The action of gossypol on rat germinal cells. Gamete Res. 13, 1-17.

Bergmeyer, H.U. \& Bernt, E. (1974) Lactate dehydrogenase. In Methods of Enzymatic Analysis, pp. 574-579. Ed. H. U. Bergmeyer. Academic Press, New York.

Beyler,S.A. \& Zaneveld, L.J.D. (1982) The male accessory sex glands. In Biochemistry of Mammalian Repro- duction, pp. 65-88. Eds L. J. D. Zaneveld \& R. T. Chatterton. J. Wiley \& Sons, New York.

Brooks, D.E. (1980) Carnitine in the male reproductive tract and its relation to the metabolism of the epididymis and spermatozoa. In Carnitine Biosynthesis and Metabolism and Functions, pp. 219-235. Eds R. A. Frenkel \& J. D. Mc Garry. Academic Press, New York.

Chang, C.C. \& Segal, S.J. (1985) Assessment of toxicity 
and antifertility efficacy of gossypol in male rats. In Gossypol, a Potential Contraceptive for Men, pp. 45-57. Ed. S. J. Segal. Plenum Press, New York.

de Kretser, D.M., Sharpe, R.M. \& Swanston, I.A. (1979) Alterations in steroidogenesis and human chorionic gonadotropin binding in the cryptorchid rat testis. Endocrinology 105, 135-138.

Garnier, D.H., Cotta, Y. \& Terqui, M. (1978) Androgen radioimmunoassay in the ram: results of direct plasma testosterone and dehydroepiandrosterone measurement and physiological evaluation. Annls Biol. anim. Biochem. Biophys. 18, 265-281.

Giridharan, N., Sesikeran, B., Bamji, M.S. \& Madhyastha, M.N. (1987) Dose and time related changes in LDH-X activity, epididymal carnitine levels and fertility, in gossypol-treated male rats. Contraception 35, 89-100.

Gustafsson, B. (1966) Luminal contents of the bovine epididymis under conditions of reduced spermatogenesis, luminal blockage and certain sperm abnormalities. Acta vet. scand., Suppl. 17, 1-80.

Hagenäs, L. \& Ritzen, E.M. (1976) Impaired Sertoli cell function in experimental cryptorchidism. Molec cell. Endocrinol. 4, 25-35.

Hoffer, A.P. (1983) Effects of gossypol on the seminiferous epithelium in the rat: a light and electron microscope study. Biol. Reprod. 28, 1007-1020.

Hofier, A.P. (1985) Ultrastuctural, biochemical and endocrine studies on the effects of gossypol and its isomeric derivatives on the male reproductive tract. In Gossypol, a Potential Contraceptive for Men, pp. 143-186. Ed. S. J. Segal. Plenum Press, New York.

Jegou, B., Risbridger, G.P. \& de Kretser, D.M. (1983) Effect of experimental cryptorchidism on testicular function in adult rats. $J$. Androl. 4, 88-94.

Jegou, B., Laws, A.O. \& de Kretser, D.M. (1984) Changes in testicular function induced by short-term exposure of rat to heat: further evidence for interaction of germ cells, Sertoli cells and Leydig cells. Int. J. Androl. 7, 244-257.

Jeulin, C., Soufir, J.C., Marson, J., Paquignon, M. \& Dacheux, J.L. (1987) The distribution of carnitine and acetylcarnitine in the epididymis and epididymal spermatozoa of the boar. J. Reprod. Fert. 79, 523-529.

Kaur, P., Khullar, M., Mittal, S. \& Rai, U.C. (1988) Effect of gossypol on testes and epididymis of albino rats. Ind. J. med. Res. 368-376.

Lee, C.Y.G., Moon, Y.S., Duleba, A., Chen, A.F., Yuan, J.H. \& Gomel, V. (1985) Biochemical studies of gossypol. In Gossypol, a Potential Contraceptive for Men, pp. 237-244. Ed. S. J. Segal. Plenum Press, New York.

Lin, T., Murono, E.P., Osterman, J., Nankin, H.R. \& Coulson, P.B. (1981) Gossypol inhibits testicular steroidogenesis. Fert. Steril. 35, 563-566.

Lowry, O.H., Rosebrough, M.T., Farr, A.L. \& Randall, R.J. (1951) Protein measurement with the Folin phenol reagent. J. biol. Chem. 193, 265-275.

Mann, T. (1975) Biochemistry of semen. In Handbook of Physiology, pp. 461-471. Ed. S. R. Geiger. American Physiology Society, Washington, DC.

Marquis, N.R.P. \& Fritz, I.B. (1964) Enzymological determination of free carnitine concentrations in rat tissues. J. Lipid. Res. 5, 184-187.
Marquis, N.R.P. \& Fritz, I.B. (1965) Effects of testosterone on the distribution of carnitine, acetylcarnitine and carnitine acetyltransferase in tissues of the reproductive system of the male rat. J. biol. Chem. 240, 2197-2200.

Menezo, Y. (1976) Milieu synthétique pour la survie et la maturation des gamètes et pour la culture de l'oeuf fécondé. C. $r$. hebd. Seanc. Acad. Sci., Paris 282D, 1967-1970.

Oko, R. \& Hrudka, F. (1982) Segmental aplasia of the mitochondrial sheath and sequelae induced by gossypol in rat spermatozoa. Biol. Reprod. 26, 183-195.

Oko, R. \& Hrudka, F. (1984) Comparison of the effects of gossypol, estradiol-17 $\beta$ and testosterone compensation on male rat reproductive organs. Biol. Reprod. 30, 1198-1207.

Pearson, D.J., Tubbs, P.K. \& Chase, F.A. (1974) Carnitine and acylcarnitines. In Methods of Enzymatic Analysis, pp. 1758-1771. Ed. H. U. Bergmeyer, Academic Press, New York.

Radigue, C., Soufir, J.C., Couvillers, M.L., Dantec, M.C. \& Folliot, R. (1988) Early effects of gossypol on the testis and epididymidis in the rat. Reprod. Nutr. Dévelop. 28, 1329-1338.

Robb, G.W., Amann, R.P. \& Killian, G.J. (1978) Daily sperm production and epididymal sperm reserves of pubertal and adult rat. J. Reprod. Fert., 54, 103-107.

Soufir, J.C., Marson, J. \& Jouannet, P. (1981) Free (L) carnitine in human seminal plasma. Int. J. Androl. 4, 388-393.

Soufir, J.C., Jouannet, P., Marson, J. \& Soumah, A. (1983) Reversible inhibition of sperm production and gonadotrophin secretion in men following combined oral medroxy-progesterone acetate and percutaneous testosterone treatment. Acta endocr., Copenh. 2, $625-632$.

Soufir, J.C., Dantec, M.C., Jegou, B. \& Folliot, R. (1984) Epididymal effect of gossypol. The Lancet 14, 106-107.

Wang, J.M., Gu, C.H., Tao, L, Wu, X.L. \& Qiu, J.P. (1986) Electrolyte composition of rete testis fluid and cauda epididymal plasma and spermatozoa from rats following gossypol treatment. Andrologia 18, 43-49.

Weissbach, A. (1974) D myo-inositol. In Methods of Enzymatic Analysis, pp. 1333-1336. Ed. H. U. Bergmeyer. Academic Press, New York.

Wong, P.Y.D., Lee, W.M., Tsang, A.Y.F., Fu, W.O. \& Chan, Q.Q. (1983) Lack of an effect of gossypol on the epididymis of the rat. Contraception 27, 391-400.

Wong, P.Y.D., Qiu, J.P. \& Fu, W.O. (1984) Gossypol does not effect testicular fluid secretion in rats. Contraception 29, $471-477$.

Zhou, L.F., Qi, S.Q. \& Lei, H.P. (1985a) Effect of gossypol acetic acid on the epididymis: scanning electron microscopic studies. In Advances in Fertility Regulation in the Male, p. 160. Eds S. Z. Quan \& G. M. H. Waites. The People's Medical Publishing House, Beijing.

Zhou, L.F., Qi, S.Q. \& Lei, H.P. (1985b) Effect of gossypol acetic acid on the epididymis: histochemical studies. In Advances in Fertility Regulation in the Male, p. 161. Eds S. Z. Quan \& G. M. H. Waites. The People's Medical Publishing House, Beijing.

Received 15 July 1988 